Short Communication

\title{
EFFECTS OF DOXYCYCLINE TREATMENT ON HEMATOLOGICAL AND BLOOD BIOCHEMICAL PARAMETERS IN DOGS NATURALLY INFECTED WITH EHRLICHIA CANIS
}

\author{
Elena Atanaskova Petrov ${ }^{1}$, Igor Ulcar ${ }^{2}$, Irena Celeska², Ksenija Ilievska ${ }^{1}$, \\ Pandorce Spasovska Trenkovska ${ }^{3}$, Todor Novakov ${ }^{1}$, Kiril Krstevski ${ }^{4}$, \\ Toni Dovenski ${ }^{5}$, Jovana Stefanovska ${ }^{6}$
}

${ }^{1}$ University Veterinary Hospital, Faculty of Veterinary Medicine, University Ss. Cyril and Methodius, Lazar Pop Trajkov 5-7, 1000 Skopje, Macedonia ${ }^{2}$ Department of Pathophysiology, Faculty of Veterinary Medicine, University Ss. Cyril and Methodius, Lazar Pop Trajkov 5-7, 1000 Skopje, Macedonia ${ }^{3}$ Veterinary Clinic D-r Naletoski, 1244 No 36, 1000 Skopje, Macedonia

${ }^{4}$ Department of Infectious Diseases, Faculty of Veterinary Medicine,

University Ss. Cyril and Methodius, Lazar Pop Trajkov 5-7, 1000 Skopje, Macedonia

${ }^{5}$ Department of Reproduction, Faculty of Veterinary Medicine,

University Ss. Cyril and Methodius, Lazar Pop Trajkov 5-7, 1000 Skopje, Macedonia ${ }^{6}$ Department of Parasitology and Parasitic Diseases, Faculty of Veterinary Medicine, University Ss. Cyril and Methodius, Lazar Pop Trajkov 5-7, 1000 Skopje, Macedonia

Received 17 March 2017; Received in revised form 7 December 2017; Accepted 11 December 2017

\begin{abstract}
Ehrlichia canis, the etiologic agent of canine monocytic ehrlichiosis (CME), is mainly transmitted by the brown dog tick Rhipicephalus sanguineus. Clinical signs of the disease can be various, depending on the stage of the disease. Typical changes in hematological and blood biochemical parameters are: severe thrombocytopenia, mild to marked non regenerative anaemia and hypoalbuminemia. In order to present the effects of the treatment protocol on several hematological and biochemistry parameters, 34 Ehrlichia canis positive dogs were compared before and after treatment with doxycycline $10 \mathrm{mg} / \mathrm{kg} / \mathrm{day}$, in duration of four weeks. Besides the clinical sings and laboratory findings, diagnosis was confirmed by antibody tests (Bionote, Korea, AGROLABO S.p.A., Italy). The most common clinical sings were depression, lethargy, pyrexia, vomiting and anorexia. Hematological analyses were performed on the automatic hematology analyzer Exigo EosVet (Sweden), while biochemistry analyses (alanine aminotransferase, aspartate aminotransferase, urea, creatinine, albumin, total protein, globulin and alkaline phosphatase) were performed using the automatic analyzer ChemWell 2910 (Awareness Technology, INC, USA). Statistically significant difference $(p<0.05)$ in hematology changes was present regarding the red blood cells count, platelet count, hematocrit and hemoglobin before and after treatment. Hypoalbuminaemia (Mean $19.21 \pm 4.96 \mathrm{~g} / \mathrm{l}$ ) was the only serum biochemistry parameter with significant change before and after treatment, as well. Treatment with doxycycline in patients with E.canis resulted in significant increase of hematology parameters (red blood cells, hemoglobin, haematocrit and platelets), as well as albumins in serum.
\end{abstract}

Key words: Ehrlichia canis, doxycycline, clinical sings, hematology, biochemical parameters

Corresponding author: Dr. Elena Atanaskova Petrov, DVM E-mail address: eatanaskova@fvm.ukim.edu.mk

Present address: University Veterinary Hospital, Faculty of Veterinary Medicine, University Ss. Cyril and Methodius, Lazar Pop Trajkov 5-7, 1000 Skopje, Macedonia

Phone: ++3892 3240778; Fax: ++ 38923114619

Copyright: (C) 2018 Atanaskova Petrov E. This is an open-access article published under the terms of the Creative Commons Attribution License which permits unrestricted use, distribution, and reproduction in any medium, provided the original author and source are credited. Competing Interests: The authors have declared that no competing interests exist.

Available Online First: 29 January 2018

Published on: 15 March 2018

https://doi.org/10.2478/macvetrev-2018-0011

\section{INTRODUCTION}

Ehrlichia canis, a Gram negative obligate intracellular bacterium is the etiologic agent of canine monocytic ehrlichiosis (CME), a potentially fatal disease in dogs, mainly transmitted in Europe by the brown dog tick Rhipicephalus sanguineus. This disease can also be transmitted by blood transfusion (1). The bacterium Ehrlichia canis 
was first identified in 1935 in Algeria, when dogs infested with ticks revealed fever and anemia (2). Since then, it has been described in tropical, subtropical and Mediterranean areas all over the world $(1,3)$. In the last years this disease has been reported in our neighboring countries Albania, Serbia, Bulgaria and Greece $(3,4,5,6)$. In R. Macedonia studies about this disease have been published recently (7).

Infection occurs when an infected tick bites the dog and infects the biting site with its saliva (8). In the organism, E. canis enters in the monocytes and macrophages of the host and spreads through the Monocyte Macrophage System in the body. Incubation period is between 8-20 days, when the bacterium multiplies in macrophages and spreads through the body. Canine monocytic ehrlichiosis, the disease caused by E. canis, is a multisystem disease characterized by three stages: acute, subacute and chronic stage. Clinical signs of the disease are various, but most often depression, anorexia, pyrexia and bleeding tendencies are present (9). Physical examination typically reveals lymphadenomegaly, splenomegaly and hemorrhagic tendencies, usually dermal petechiae and ecchymoses, as well as epistaxis. The most common hematological and blood biochemical changes are: severe thrombocytopenia, mild to marked anemia and hypoalbuminemia (10). According to Neer at al. (11) clinical signs, clinicopathologic abnormalities, together with positive serology finding are sufficient for clinical diagnosis of ehrlichiosis.

Tetracyclines, especially doxycycline, are most commonly used antibiotics in the treatment of many bacterial infections transmitted by ticks (12). Doxycycline is an often prescribed medication due to its antimicrobial properties and pleiotropic functions, independent of its antimicrobial activity. There are other immunomodulatory and/or antiinflammatory properties of this medication, associated with effects on blood leukocyte proliferation and function, cytokine synthesis and matrix metalloproteinase activity (13).

There are contradictory opinions about the efficiency of doxycycline, some authors reported persistence of infection after 7 to 85 days treatment $(14,15,16)$, while others reported successful elimination of E. canis after 14 to 60 days treatment $(17,18,19)$. Treatment duration seems to be more important than dosage or frequency of administration.

The usual treatment of canine ehrlichiosis includes antibiotic doxycicline $10 \mathrm{mg} / \mathrm{kg} / 24 \mathrm{~h}$ for 28 days and symptomatic therapy (fluids, vitamins, antipyretics etc.), and blood transfusion in severe cases (11). Clinical improvement usually appears before normalization of the hematologic and biochemistry values, as other authors already have noted (20). Among the laboratory findings, $\mathrm{RBC}$ and platelet counts are the parameters that first return to normal, often reaching reference values by the end of the treatment period, which indicates good response to therapy (21). Gradual resolution of hyperglobulinemia over 6-9 months also suggests therapeutic elimination of the organism. For this reason, monitoring hematology and biochemistry parameters could be considered a valuable prognostic aid in association with the clinical response.

The aim of this study was to analyze the most common changes in the hematological and blood biochemical parameters before and after treatment the naturally infected dogs with doxycycline.

\section{MATERIAL AND METHODS}

This study covered 34 Erlichia canis positive dogs from the University Veterinary Hospital in Skopje, analyzed before and after treatment. Patients were admitted in the hospital for clinical examination due to different signs of the disease. Detailed anamnestic data was obtained and clinical examination was performed in all dogs. According to the anamnestic data, the owners confirmed the presence of tick infestation, despite using ectoparasitic prevention. Samples for biochemistry (serum samples) and hematology (whole blood) were taken by vein-puncture of cephalic or saphenous vein in tubes with anticoagulant (EDTA) and sera tubes.

Based on previous studies about laboratory changes in whole blood and sera from patient with CMA, haematology and biochemistry analyses were performed $(22,23)$.

Complete blood counts were performed on the automatic hematology analyzer Exigo EosVet (Sweden) with the following data: red blood cells (RBC), white blood cells (WBC), hemoglobin $(\mathrm{Hb})$, hematocrit $(\mathrm{HCT})$, platelet count (PLT) and differential leukocyte count. Serum biochemistry analyses were performed using the automatic analyzer ChemWell 2910 (Awareness Technology, INC, USA), and included alanine aminotransferase (ALT), aspartate aminotransferase (AST), urea, creatinine, albumin, total protein and globulin, alkaline phosphatase (ALP), with spectrophotometric kinetic and "end 
point" methods, according to the manufacturer's instructions (Human, Germany).

Based on the anamnesis, hematology and biochemistry findings, there were indications about the presence of canine monocityc ehrlichiosis. Infection with $E$. canis was confirmed using a whole blood or sera with chromatographic immunoassay antibody snap test, according the manufacturer's instructions (BioNote, Korea). The serum samples were also screened for detection of $\operatorname{IgG}$ antibodies against $E$. canis, using a micro-immunofluorescent assay (Biopronix Ehrlichia 96, AGROLABO S.p.A, Italy) according to the manufactures recommendation (optical density $>1$ was considered as positive result). Erlichia canis positive dogs were a mixed population of ages, breeds, gender and origin. We used treatment protocol according to Neer et al. 2002, with doxycycline (10 mg/kg/day for 28 days) (11).

Statistical analysis was performed using STATISTICA for Windows 7, (StatSoft) software and significance of the differences was analyzed by Student's t- test. Value of $\mathrm{p}<0.05$ was taken for statistical significance.

\section{RESULTS}

After collecting and processing all data (clinical and laboratory findings), comparisons between the results were made. All of the dogs that were positive on the snap test were confirmed by the serological analyses. Most common clinical signs during the clinical examination were depression (73.5\%), pyrexia (58.8\%), and digestive disorders (anorexia, vomiting or diarrhea) (41\%) (Table 1). Clinical signs resolved after treatment. Average age of the patients was 4.3 years (youngest dog was 6 months old, oldest 11 years), while regarding the gender male dogs were more prevalent then female (70.6\%).

Table 1. Clinical sings on physical examination of patients with CME

\begin{tabular}{lc}
\hline Symptoms & Number of dogs (\%) \\
\hline Digestive tract (vomiting, anorexia diarrhea,) & $14(41 \%)$ \\
Enlarged Lymph nodes & $8(23 \%)$ \\
Bleeding tendencies (epistaxis, melena, hematoma) & $9(26.5 \%)$ \\
Skin (hemorrhages, petechiae, ecchymoses) & $8(23.5 \%)$ \\
Respiratory system (couch, labor breeding, dyspnea, tachypnea) & $4(11.8 \%)$ \\
Urinary tract (poliuria, anuria, pain in the kidney region) & $3(8.8 \%)$ \\
Pyrexia & $20(58.8 \%)$ \\
Depression/lethargy & $25(73.5 \%)$ \\
Ocular discharge & $7(20.5 \%)$ \\
Ascites/Oedema & $1(2.9 \%)$ \\
\hline
\end{tabular}

*Total number of dogs - 34

Table 2. Mean \pm standard deviation changes in hematological parameters in dogs with canine monocytic ehrlichiosis (CME) before and after treatment with doxycycline

\begin{tabular}{lcccc}
\hline & Before treatment & $\begin{array}{c}\text { After treatment } \\
(\mathbf{2 8} \text { days })\end{array}$ & $\begin{array}{c}\text { Referent } \\
\text { ranges }\end{array}$ & *P value \\
\hline Red Blood cell count $\left(\mathrm{x} 10^{12} / \mathrm{l}\right)$ & $4.31 \pm 1.39$ & $5.64 \pm 1.36$ & $5,5-8,5$ & 0.0002 \\
Haemoglobin $(\mathrm{g} / \mathrm{dl})$ & $10.22 \pm 3.19$ & $13.23 \pm 2.86$ & $12-18$ & 0.0001 \\
Haematocrit $(\%)$ & $24.44 \pm 8.97$ & $32.34 \pm 9.99$ & $37-55$ & 0.0011 \\
Platelet count $\left(\mathrm{x} 10^{9} / \mathrm{l}\right)$ & $96.79 \pm 60.39$ & $256.38 \pm 86.22$ & $200-500$ & 0.0000 \\
White blood cell count $\left(\mathrm{x} 10^{9} / 1\right)$ & $11.11 \pm 6.01$ & $12.31 \pm 6.75$ & $6,0-17,0$ & 0.4392 \\
Neutrophils $\left(\mathrm{x} 10^{9} / 1\right)$ & $6.59 \pm 4.54$ & $7.90 \pm 5.42$ & $3,5-12,0$ & 0.2833 \\
Lymphocytes $\left(\mathrm{x} 10^{9} / 1\right)$ & $2.96 \pm 2.35$ & $2.98 \pm 1.81$ & $1,2-5,0$ & 0.9586 \\
Monocytes $\left(\mathrm{x} 10^{9} / \mathrm{l}\right)$ & $1.12 \pm 1.10$ & $0.95 \pm 0.58$ & $0,3-1,5$ & 0.4319 \\
\hline
\end{tabular}

*P values for comparison between patient before and after treatment. (Student $\mathrm{t}-$ test) 
Table 3. Mean \pm standard deviation changes in serum-biochemistry parameters in dogs with canine monocytic ehrlichiosis (CME) before and after treatment with doxycycline

\begin{tabular}{lcccc}
\hline & Before treatment & $\begin{array}{c}\text { After treatment } \\
(\text { (28days) }\end{array}$ & Referent ranges & $* \mathbf{P}$ \\
\hline AST (U/l) & $39.2 \pm 21.32$ & $31.75 \pm 12.12$ & $8,9-48,5$ & 0.1279 \\
ALT (U/1) & $70.6 \pm 49.75$ & $61.71 \pm 40.53$ & $8,2-57,3$ & 0.4832 \\
ALP (U/l) & $222.51 \pm 279.04$ & $175.51 \pm 258.27$ & $10,6-100,7$ & 0.5352 \\
Albumins (g/l) & $19.21 \pm 4.96$ & $23.29 \pm 5.08$ & $25,8-39,7$ & 0.0055 \\
Globulins $(\mathrm{g} / \mathrm{l})$ & $45.24 \pm 27.37$ & $36.73 \pm 11.97$ & $20,6-37,0$ & 0.1539 \\
Total protein $(\mathrm{g} / \mathrm{l})$ & $64.49 \pm 27.66$ & $60.02 \pm 10.96$ & $55,1-75,2$ & 0.4486 \\
Urea $(\mathrm{mmol} / \mathrm{l})$ & $8.09 \pm 8.21$ & $5.98 \pm 5.14$ & $3,1-9,2$ & 0.2761 \\
Creatinine $(\mu \mathrm{mol} / \mathrm{l})$ & $110.63 \pm 40.54$ & $88.31 \pm 36.10$ & $44,3-138,4$ & 0.0844 \\
\hline
\end{tabular}

*P values for comparison between patient before and after treatment. (Student t- test)

Hematological results revealed statistically significant difference regarding the RBC, HCT, $\mathrm{Hb}$ and PLT (Table 2) before and after treatment. Haemoglobin $(\mathrm{g} / \mathrm{L})$ and platelet count $\left(\mathrm{x} 10^{12} / \mathrm{L}\right)$ showed a high statistically significant difference $(p<0.0001)$ before and after treatment.

Blood biochemical parameters results have demonstrated statistical significance in the values for the albumin $(\mathrm{p}<0.005)$ (Table 3$)$.

Our study demonstrated that doxycycline treatment for 4 weeks resulted in increased platelet and erythrocyte number in CME affected dogs, as previously described $(21,24)$.

\section{DISCUSSION}

Canine monocytic ehrlichiosis is a tick borne disease and may be manifested by a variety of clinical sings. Similar to Nakaghi et al. (23), in our study the most common clinical sings were depression and lethargy (73.5\%), pyrexia (58.8\%), vomiting or anorexia (41\%). These clinical signs are easy noticeable by the owners and clinical examination confirmed the condition of illness.

During the acute phase, when bacteremia occurs, severe haemo-pathological changes appeared as well as some biochemical alteration. In our study, the obtained results for hematological parameters (RBC, Hb, HCT and PLT) before treatment were significantly decreased from the reference ranges. The thrombocytopenia is a main marker of this disease (25). The mechanisms involved in the pathogenesis are increased destruction of the platelets due to inflammatory changes of the blood vessels endothelium and increased platelet sequestration in the spleen. These results are presented in significant difference in PLT $(\mathrm{p} \leq 0.001)$ number before and after treatment (18). Villaescusa et al. (26) reported increase in PLT in healthy patients treated with doxycycline, claiming that besides antimicrobial activity it has effect on platelet proliferation. In contrast of this study Webb at al. (27) reported that there wasn't any change in the platelet count or function in healthy dogs treated with doxycycline. Further studies on a larger group of dogs are necessary in order to clarify these findings. Hypergammaglobulinemia induced immune-mediated platelet destruction (8, 9). Abnormal hematology findings are present due to tropism for hematopoietic cells and bone marrow hypoplasia, such as suppression in erythroid, myeloid, and megakaryocytic cells. The anemia is non regenerative, as a result of progressive replication of Ehrlichia canis in the bone marrow and inhibition effect of colony forming units in the process of erythropesis and megacariopoesis (28). Our results are in accordance with this pathogenic mechanism, showed in the significant difference in hematology parameters such as RBC $(\mathrm{p} \leq 0.001)$, HCT $(\mathrm{p} \leq 0.01)$, and $\mathrm{Hb}(\mathrm{p} \leq 0.001)$, which is a common finding by other authors $(29,30)$. Regarding biochemical parameters before treatment, marked hypoalbuminemia was noted, followed by hyperglobulinemia. Similar results are reported by other authors $(26,30)$. Serum concentration of urea and creatinine were in reference ranges before and after treatment, but these parameters usually change in the chronic stage of the disease (31). Other biochemical parameters such as ALT, AST and ALKP, showed slight changes in serum concentration before and after treatment, but there was not a statistically significant difference. Some authors reported increase in ALP and ALT in dogs in naturally infected dogs $(31,32)$. 


\section{CONCLUSION}

Thrombocytopenia, anemia and hypoalbuminemia are characteristic laboratory findings in patients with CME. Treatment protocol with doxycycline for 28 days, besides resolving the clinical signs, effects on increasing of the RBC, PLT, Hb, HCT and albumins in dogs naturally infected with $E$. canis.

\section{CONFLICT OF INTEREST STATEMENT}

The authors declared that they have no potential conflict of interest with respect to the authorship and/or publication of this article.

\section{ACKNOWLEDGEMENT}

This research was part of a national project "Improved clinical and diagnostic approach of the prevalence of canine ehrlichiosis in R.Macedonia", funded by the University Ss Cyril and Methodius, Skopje 2015/16 (02640/23).

\section{REFERENCES}

1. Baneth, G., Harrus, S., Ohnona, F. S., Schlesinger, Y. (2009). Longitudinal quantification of Ehrlichia canis in experimental infection with comparison to natural infection. Vet Microbiol. 136 (3): 321-325. https://doi.org/10.1016/j.vetmic.2008.11.022 PMid:19128893

2. Donatien, A., Lestoquard, F. (1935). Existence en Algerie d'une rickettsia du chien. Bull Soc Pathol Exot. 28, 418-419.

3. Kontos, V.I., Athanasiou, L.V., Bitschava D. (1998). Serological study of erhlichiosis in dogs with clinical leishmaniasis. J Hellenic Vet Med Soc. 171-174.

4. Hamel, D., Silaghi, C., Knaus, M., Visser, M., Kusi, I., Rapti, D., Pfister, K. (2009). Detection of Babesia canis subspecies and other arthropod-borne diseases in dogs from Tirana, Albania. Wien Klin Wochenschr. 121 (3): 42-45. https://doi.org/10.1007/s00508-009-1234-3 PMid:19915816

5. Potkonjak, A., Savic, S., Jurisic, A., Petrovic, A., Suvajdzic, L., Lako, B., Novakovic, Z. (2013). Seroepidemiological research of canine monocytic ehrlichiosis in the autonomous province of Vojvodina, Serbia. Acta Sci Vet. 41 (1106): 1-8.
6. Tsachev, I., Papadogiannakis, E. I., Kontos, V., Zarkov, I., Petrov, V., Pelagic, V. (2006). Seroprevalence of Ehrlichia canis infection among privately-owned dogs in northern Bulgaria (In Greek and English). J Hellenic Vet Med Soc. 57 (3): 212-216.

7. Stefanovska, J., Kochevsk,i Z., Iskra, C., Farkas, R., Naletoski, I., Mrenoshki, S., Mitrov, D., Pendovski, L. (2012). Serological evidence of Ehrlichia canis and Leishmania infantum co-infection in naturally exposed dogs on the territory of Republic of Macedonia. Proceedings of the 3rd International Scientific Meeting Days of Veterinary Medicine, September, 2-4, (pp. 38-39), Ohrid, Macedonia.

8. Waner, T., Keysary, A., Bark, H., Sharabani, E., Harrus, S. (1999). Canine monocytic ehrlichiosis-an overview. Isr J Vet Med. 54 (4): 103-107.

9. Mylonakis, M. E., Theodorou, K. N. (2017). Canine monocytic ehrlichiosis: An update on diagnosis and treatment. Acta Vet (Beogr). 67 (3): 299-317. https://doi.org/10.1515/acve-2017-0025

10. Waner, T., Harrus, S. (2013). Canine monocytic ehrlichiosis-from pathology to clinical manifestations. Isr J Vet Med. 68 (1): 12-18.

11. Neer, T.M., Breitschwerdt, E.B., Greene, R.T., Lappin, M.R. (2002). Consensus statement on ehrlichial disease of small animals from the infectious disease study group of the ACVIM. J Vet Intern Med. 16, 309-315.

PMid:12041661

12. Woody, B. J., Hoskins, J. D. (1991). Ehrlichial diseases of dogs. Vet Clin N Am Small Anim Pract. 21, 75-98. https://doi.org/10.1016/S0195-5616(91)50009-7

13. Griffin, M.O., Fricovsky, E., Ceballos, G., Villarreal, F.J. (2010). Tetracyclines: A pleiotropic family of compounds with promising therapeutic properties. Am J Physiol Cell Physiol. 299, 539-548. https://doi.org/10.1152/ajpcell.00047.2010 PMid:20592239 PMCid:PMC2944325

14. Bartsch, R.C., Greene, R.T. (1996). Post-therapy antibody titers in dogs with ehrlichiosis: followup study on 68 patients treated primarily with tetracycline and/or doxycycline. J Vet Intern Med. 10, 271-274.

https://doi.org/10.1111/j.1939-1676.1996.tb02061.x PMid:8819054

15. Wen, B., Rikihisa, Y., Mott, J.M., Greene, R., Kim, H.Y., Zhi, N., Couto, G.C., Unver, A. Bartsch, R. (1997). Comparison of nested PCR with immunofluorescent-antibody assay for detection of Ehrlichia canis infection in dogs treated with doxycycline. J Clin Microbiol. 35 (7): 1852-1855. PMid:9196207 PMCid:PMC229855 
16. Iqbal, Z., Rikihisa, Y. (1994). Reisolation of Ehrlichia canis from blood and tissues of dogs after doxycycline treatment. J Clin Microbiol. 32, 1644- 1649. PMid:7929751 PMCid:PMC263749

17. Harrus, S., Kenny, M., Miara, L., Aizenberg, I., Waner, T. Shaw, S. (2004). Comparison of simultaneous splenic sample PCR with blood sample PCR for diagnosis and treatment of experimental Ehrlichia canis infection. Antimicrob Chemoth. 48, 4488-4490.

https://doi.org/10.1128/AAC.48.11.4488-4490.2004 PMid:15504892 PMCid:PMC525421

18. Schaefer, J. J., Kahn, J., Needham, G. R., Rikihisa, Y., Ewing, S. A., Stich, R. W. (2008). Antibiotic clearance of Ehrlichia canis from dogs infected by intravenous inoculation of carrier blood. Ann N Y Acad Sci. 1149, 263- 269.

https://doi.org/10.1196/annals.1428.087

PMid:19120226 PMCid:PMC3052985

19. Breitschwerdt, E. B., Hegarty, B. C., Hancock, S. I. (1998). Doxycycline hyclate treatment of experimental canine ehrlichiosis followed by challenge inoculation with two Ehrlichia canis strains. Antimicrob Agents Chemother. 42, 362-368.

PMid:9527787 PMCid:PMC105415

20. Troy, G. C., Forrester, S. D. (1990). Ehrlichia canis, E. equi, and E. Risticii infections. In: Greene CE (Ed.), Infectious Diseases of the Dog and Cat (pp. 404-414). Philadelphia, PA: WB Saunders.

21. Sainz, A., Tesouro, M. A., Amusategui, I., Rodriguez, F., Mazzucchelli, F., Rodriguez, M. (2000). Prospective comparative study of 3 treatment protocols using doxycycline or imidocarb dipropionate in dogs with naturally occurring ehrlichiosis. J Vet Intern Med. 14 (2): 134-139. https://doi.org/10.1111/j.1939-1676.2000.tb02226.x PMid:10772483

22. Spasojević-Kosić, L., Savić, S., Potkonjak, A., Vračar, V. (2015). Retrospective analysis of clinical and laboratory findings in hunting dogs with serologic reactions to tick-borne pathogens (Anaplasma phagocytophilum, Borrelia burgdorferi, Babesia canis, Ehrlichia canis, Ricketsia conorii). Vet glas. 69 (3-4): 219-232.
23. Nakaghi, A. C. H., Machado, R. Z., Costa, M. T., André, M. R., Baldani, C. D. (2008). Canine ehrlichiosis: clinical, hematological, serological and molecular aspects. Ciênc Rural. 38 (3): 766-770. https://doi.org/10.1590/S0103-84782008000300027

24. Neer, T.M. (1995). Ehrlichiosis update. Proceedings of the 13th Annual Congress of the American College of Veterinary Internal Medicine. San Diego, California, United States of America. Proceedings. pp. 822-826.

25. Neer, T.M., Harrus, S. (2006). Canine monocytotropic ehrlichiosis and neorickettsiosis (E. canis, E. chaffeensis, E. ruminantium, N. sennetsu, and N. risticii infections). In: Greene, C.E. (Ed.), Infectious diseases of the dog and cat, Third Ed. Saunders Elsevier (pp. 203-216). St. Louis, MO, USA.

26. Villaescusa, A., García-Sancho, M., RodríguezFranco, F., Tesouro, M. Á., Sainz, Á. (2015). Effects of doxycycline on haematology, blood chemistry and peripheral blood lymphocyte subsets of healthy dogs and dogs naturally infected with Ehrlichia canis. Vet J. 204 (3): 263-268.

https://doi.org/10.1016/j.tvj1.2015.03.031

PMid:25957920

27. Webb, J. A., Allen, D. G., Abrams-Ogg, A. C., Gentry, P. A. (2006). Effects of doxycycline, amoxicillin, cephalexin, and enrofloxacin on hemostasis in healthy dogs. Am J Vet Res. 67 (4): 569-576.

https://doi.org/10.2460/ajvr.67.4.569

PMid:16579747

28. Abeygunavardena, I., I. Kakoma, Smith, R. D. (1990). Pathophysiology of canine ehrlichiosis, In: J. C. Williams and I. Kakoma (Eds.), Ehrlichiosis, a vectorborne disease of animals and humans (pp. 78-92). Boston: Kluwer Academic Publishers.

29. de Castro, M. B., Machado, R. Z., de Aquino, L. P. C. T., Alessi, A. C., Costa, M. T. (2004). Experimental acute canine monocytic ehrlichiosis: clinicopathological and immunopathological findings. Vet Parasitol. 119 (1): 73-86. https://doi.org/10.1016/j.vetpar.2003.10.012 PMid:15036578 
30. Harrus, S., Kass, P. H., Klement, E., Waner, T. (1997). Canine monocytic ehrlichiosis: a retrospective study of 100 cases, and an epidemiological investigation of prognostic indicators for the disease. Vet Rec. 141 (14): 360-363.

https://doi.org/10.1136/vr.141.14.360

PMid:9351183

31. Frank, J. R., Breitschwerdt, E. B. (1999). A retrospective study of ehrlichiosis in 62 dogs from North Carolina and Virginia. J Vet Intern Med. 13 (3): 194-201.

https://doi.org/10.1111/j.1939-1676.1999.tb02178.x

PMid:10357108
32. Mylonakis, M. E., Kritsepi-Konstantinou, M.. Dumler, J. S., Diniz, P.V.P., Day, M. J., Siarkou, V. I., Breitschwerdt, E. B., Psychas, V., Petanides, T., Koutinas, A. F. (2010). Severe hepatitis associated with acute Ehrlichia canis infection in a dog. J Vet Intern Med. 24 (3): 633-638.

https://doi.org/10.1111/j.1939-1676.2010.0501.x PMid:20384948 